\title{
Curcumin restores sensitivity to retinoic acid in triple negative breast cancer cells
}

\author{
Padmamalini Thulasiraman*, Daniel J McAndrews and Imran Q Mohiudddin
}

\begin{abstract}
Background: A major obstacle in the use of retinoid therapy in cancer is the resistance to this agent in tumors. Retinoic acid facilitates the growth of mammary carcinoma cells which express high levels of fatty acid-binding protein 5 (FABP5). This protein delivers retinoic acid to peroxisome proliferator-activated receptor $\beta / \delta(P P A R \beta / \delta)$ that targets genes involved in cell proliferation and survival. One approach to overcome resistance of mammary carcinoma cells to retinoic acid is to target and suppress the FABP5/ PPARB/ $\delta$ pathway. The objective of this research was to investigate the effect of curcumin, a polyphenol extract from the plant Curcuma longa, on the FABP5/ PPAR $/ \delta$ pathway in retinoic acid resistant triple negative breast cancer cells.

Methods: Cell viability and proliferation of triple negative breast cancer cell lines (MDA-MB-231 and MD-MB-468) treated with curcumin and/or retinoic was analyzed using 3-(4,5-dimethylthiazol-2-yl)-2,5-diphenyltetrazolium bromide (MTT) and 5-bromo-2'-deoxyuridine (BrdU). Expression level of FABP5 and PPAR $\beta / \delta$ in these cells treated with curcumin was examined by Western Blotting analysis and Quantitative Real-Time Polymerase Chain Reaction (qRT-PCR). Effect of curcumin and retinoic acid on PPARß/ $\delta$ target genes, PDK1and VEGF-A were also examined using qRT-PCR. Western Blotting was utilized to examine the protein expression level of the p65 subunit of NF-kB.

Results: Treatment of retinoic acid resistant triple negative breast cancer cells with curcumin sensitized these cells to retinoic acid mediated growth suppression, as well as suppressed incorporation of BrdU. Further studies demonstrated that curcumin showed a marked reduction in the expression level of FABP5 and PPAR $\beta / \delta$. We provide evidence that curcumin suppresses $\mathrm{p65}$, a transcription factor known to regulate FABP5. The combination of curcumin with retinoic acid suppressed PPARß/ $\delta$ target genes, VEGF-A and PDK1.
\end{abstract}

Conclusions: Curcumin suppresses the expression level of FABP5 and PPAR $\beta / \delta$ in triple negative mammary carcinoma cells. By targeting the FABP5/PPAR $\beta / \delta$ pathway, curcumin prevents the delivery of retinoic acid to PPAR $\beta / \delta$ and suppresses retinoic acid-induced PPARß/ $\delta$ target gene, VEGF-A. Our data demonstrates that suppression of the FABP5/ PPARß/ $\delta$ pathway by curcumin sensitizes retinoic acid resistant triple negative breast cancer cells to retinoic acid mediated growth suppression.

Keywords: Curcumin, Retinoic acid, Triple negative breast cancer, Fatty acid binding protein 5, Peroxisome proliferator-activated receptor $\beta / \delta$

\section{Background}

Although breast cancer is the second most leading cause of death among women in the western world, early detection and new treatments have improved survival rates [1]. However, no effective treatment for metastatic, triple negative breast cancer (TNBC) is available following surgery, radiation and chemotherapy for the primary

\footnotetext{
* Correspondence: pthulasiraman@southalabama.edu

Department of Biomedical Sciences, College of Allied Health, University of South Alabama, Mobile, Al, USA
}

tumor [2,3]. This subtype of breast cancer accounts for $15-20 \%$ of all breast cancers and the signature of TNBCs is the lack of the estrogen receptor, progesterone receptor and the lack of the overexpression of HER2 [4,5]. Drug resistance is a major problem in TNBC patients, promoting the need to understand the molecular mechanisms involved in the disease and identify future targeted therapy. Several promising agents are currently under clinical trials for the prevention 
of TNBC which include poly (ADP-ribose) polymerase inhibitors, vitamin $\mathrm{D}$ and rexinoids [6].

Anticancer drugs, derived from natural sources, have been used alone or in combination with traditional drugs to treat multiple diseases, including cancer [7-9]. Curcumin derived from the plant Curcuma longa has been used as a dietary agent, food preservative and a longtime favorite Asian medicinal treatment [10]. It is a hydrophobic polyphenol derived from turmeric (Curcuma longa) that has anti-oxidant, anti-inflammatory and anticancer properties, promoting its potential for targeting various diseases, including cancer, arthritis, atherosclerosis, diabetes, and auto-immune diseases [11,12]. Curcumin has exhibited inhibitory effects on several malignant cancers, including breast cancer [13-16]. It has been used in clinical trials for colorectal cancer [17] and pancreatic cancer [18], and its use in combination with other therapeutic drugs promotes the suppression of tumor growth [19-21]. Due to the low bioavailability and high metabolic instability of curcumin, development of analogs of curcumin and nanocurcumin to improve their chemotherapeutic efficacies are being investigated as next generation targeted therapy $[22,23]$. Despite its current limitations, curcumin is highlighted for its efficacy in chemoprevention and reversing chemo-resistance in certain tumors [24-26]. The ability of curcumin and its analogs to enhance the efficacy of existing chemotherapeutic agents will add value for its use in the treatment of highly aggressive chemo-resistant breast tumors.

The effect of curcumin is in part due to its ability to interfere with multiple signaling cascades such as cell cycle regulators, apoptotic proteins, pro-inflammatory cytokines, proliferative regulators and transcription factors such as nuclear factor-kappa B (NF-kB) and Stat3 [27]. It inhibits cancer cell and tumor growth, suppresses proliferation, and blocks angiogenesis and inflammation. Due to its pleiotropic effect, the role of curcumin to regulate various signaling pathways and genes have been reported in different cancer cell lines [28].

The use of retinoid therapy in cancer is promoted by the ability of retinoids to induce differentiation, cell cycle cycle arrest and apoptosis [29,30]. Due to its favorable effect on the treatment of acute promyelocytic leukemia, retinoids are being tested in clinical trials in several tumor types [31]. Vitamin A metabolite, retinoic acid (RA) transduces its signals by binding to specific nuclear hormone receptors termed retinoic acid receptors (RAR), which include RAR $\alpha, \beta$, and $\gamma$ [32]. These receptors exist as predominately RAR/RXR heterodimers and to a lesser extent RXR/RXR homodimer [33,34]. RARs bind to all-trans-RA (ATRA) or 9-cis-retinoic acid, whereas RXRs bind specifically to 9-cis-retinoic acid. The ligandreceptor complex acts as a transcription factor which binds to a specific DNA sequence element found on the promoter regions of target genes called retinoic acid response element (RARE) [32-35]. Transcriptional activation of RARs leads to differentiation and growth arrest [36,37], as well as apoptosis [38-41], establishing a prominent role of its use in anti-cancer therapy [31]. Interestingly, RA has an alternative function and in some tissues RA promotes cell growth [41-46], and paradoxically facilitates tumor development. It has been well established that RA translates its pro-carcinogenic properties in a RAR-independent mechanism through activation of the nuclear receptor, peroxisome proliferatoractivated receptor $\beta / \delta(\operatorname{PPAR} \beta / \delta)$ and its target genes $[41,42]$. Studies have shown that fatty-acid binding protein 5 (FABP5) facilitates the transfer of ligands from the cytoplasm to PPAR $\beta / \delta$, which enhances PPAR $\beta /$ $\delta$ target genes that are directly involved in proliferative responses and cell survival, promoting cell growth and protection against apoptosis $[47,48]$. PPAR $\beta / \delta$ has been implicated in the growth of other human cancers, including lung carcinoma, breast cancer and colon cancer [49]. This nuclear receptor is well known to regulate the expression of angiogenic factor, vascular endothelial growth factor A (VEGF-A), pro-survival signals of PDK1/Akt, and anti-apoptotic protein, 14-33epsilon $[41,42,50]$.

The importance of FABP5 as a prognostic marker in breast cancer patients was studied in a cohort of breast tissues, pinpointing that elevated levels of FABP5 was correlated with tumor grade and poor prognosis [51]. Not only are elevated levels of FABP5 a key determinant in the tumorigenic properties of mammary carcinoma [52], but also pancreatic cancer cell subtypes with elevated levels of FABP5 were associated with migration and invasion of cells, paralleling to lack of tumor growth inhibition [53]. High FABP5 protein expression was evident in short term glioblastoma survivors with highly proliferating tumors compared to long term glioblastoma survivors [54]. In light of the mounting evidence on the role of FABP5 in cancer cell lines, FABP5 may serve as a novel prognostic marker and inhibiting FABP5 can serve as a potential combinatorial treatment to sensitize mammary carcinoma cells to retinoid therapy.

In this study, we report that curcumin blocks cell proliferation in RA-resistant TNBC cell lines by inhibiting FABP5. It sensitizes these cells to RA mediated growth suppression. The effect of curcumin in enhancing the inhibitory effects of RA in TNBC cells is the result of diminished expression of FABP5 and PPAR $\beta / \delta$. Furthermore, we have identified a possible mechanism responsible for growth suppression by curcumin and RA. Understanding the mechanisms by which curcumin reverses the resistance of breast cancer to RA may provide alternate treatments for RA-resistant TNBC patients. 


\section{Methods Reagents}

As previously described [55,56], antibodies against FABP5 were obtained from $\mathrm{R} \& \mathrm{D}$ systems and $\beta$-tubulin was purchased from Sigma Aldrich Co (St. Louis, MO). Antibodies for PPAR $\beta / \delta$ and p65 were obtained from Santa Cruz (Santa Cruz, CA) and Cell Signaling (Boston, MA), respectively. Use of PPAR $\beta / \delta$ and $p 65$ antibodies was referenced in $[57,58]$, respectively. Antibody against $\beta$-actin was purchased from Cell Signaling (Boston, MA). Anti-mouse and anti-rabbit immunoglobulin horseradish peroxidase-conjugated antibodies were from BioRad, and anti-goat immunoglobulin was from Santa Cruz. Curcumin (C-1386) and all-trans-retinoic acid (R-2625) were obtained from Sigma. MTT reagent (3-(4, 5-dimethylthiazol-2-yl)-2,5-diphenyl tetrazolium bromide) was purchased from Sigma.

\section{Cells}

MDA-MB-231, MDA-MB-468, SkBr3 and MCF-7 cells were maintained in Dulbecco's Modified Eagle's Medium (DMEM) supplemented with 10\% fetal bovine serum (FBS) and antibiotics. MDA-MB-468 was purchased from American Type Culture Collection (Manassas, VA).

\section{RA and Curcumin Preparation}

A small amount of all-trans-RA was added to a $1 \mathrm{~mL}$ aliquot of $100 \%$ ethanol in the dark and rotated for 45 minutes at $4^{\circ} \mathrm{C}$. The absorbance of RA was measured at $350 \mathrm{~nm}$ and the extinction coefficient of RA $\left(\varepsilon=45,300 \mathrm{M}^{-1} \mathrm{~cm}^{-1}\right)$ was used to calculate the concentration of RA. A Stock of $1 \mathrm{mM}$ was prepared and used for treatment of cells. Curcumin was freshly prepared each time at a stock concentration of $50 \mathrm{mM}$ in dimethyl sulfoxide (DMSO) and diluted at the appropriate concentration for treatment of cells.

\section{Western blots}

Cells were cultured in $100 \mathrm{~mm}$ plates and treated with DMSO or curcumin for 24 hours. Cells were lysed in a buffer containing $150 \mathrm{mM} \mathrm{NaCl}, 10 \mathrm{mM}$ Tris, $\mathrm{pH}$ 7.2, $0.1 \%$ SDS, $1 \%$ Triton X-100, $1 \%$ deoxycholate, $5 \mathrm{mM}$ EDTA, and $1 \mathrm{mM}$ PMSF. Cells were lysed on ice for 1 hour and protein concentration was determined by the Bradford Assay. Cell lysate was resolved by SDS-PAGE and probed using the appropriate antibody. Anti- $\beta$-tubulin or anti- $\beta$-actin was used for loading control.

\section{Quantitative Real-Time Polymerase Chain Reaction (qRT-PCR)}

Cells were treated with curcumin and/or ATRA, and RNA was extracted using Trizol (Life Technologies, Grand, Island, NY). As described in the high capacity RNA to cDNA kit from Applied Biosystems (Gaitherburg,
MD), $2 \mu \mathrm{g}$ total RNA was reverse transcribed into cDNA. To determine expression of FABP5, PPAR $\beta / \delta$ and PDK1, and VEGF-A, qRT-PCR was carried out by using commercially available Taqman Chemistry and Assay on Demand Probes (Applied Biosystems). GAPDH was used for normalization. Detection and data analysis were carried out on the ABI Step One Plus Real-Time PCR System.

\section{siRNA knockdown experiments}

NF-kB p65 siRNA was purchased from Santa Cruz Biotechnology. Briefly, $2 \times 10^{5}$ MDA-MB-231 cells were plated in 6-well plates and transfected with $1 \mu \mathrm{g}$ of p65 siRNA or control siRNA oligos using lipofectamine 2000 as per the manufacturer's instructions. Cells were incubated for 24 hours after which cells were harvested and analyzed for p65 and FABP5 expression using Western blot analysis.

\section{Cell Proliferation MTT Assay}

MDA-MB-231 and MDA-MB-468 cells (2500 cells/well) were seeded in a 96 well plate with Dulbecco's modified Eagle's medium, 10\% charcoal treated FBS and supplemented with antibiotics, and allowed to adhere overnight. Cells were then treated with $30 \mathrm{uM}$ curcumin and/or 1 uM ATRA for 48 hours. Controls were treated with $0.1 \%$ DMSO, $0.1 \%$ ethanol and/or the combination of both. After 48 hours, $5 \mu \mathrm{g} / \mathrm{ml}$ MTT reagent (3- $(4,5-$ dimethylthiazol-2-yl)-2, 5-diphenyl tetrazolium bromide) was added directly to the cells for 3 hours, or until crystals formed. The media was carefully removed from the plate, leaving the cells intact and the cells were then resuspended in $150 \mu \mathrm{l}$ of $0.04 \mathrm{M} \mathrm{HCl}$ in isopropanol. Absorbance was read at $570 \mathrm{~nm}$ to determine cell proliferation.

\section{BrdU (5-bromo-2'-deoxyuridine) cell proliferation assay} Cell Proliferation was also measured by the incorporation of BrdU in cells by using the BrdU cell proliferation kit from Cell Signaling. MDA-MB-231 cells were plated in 96-well plates and treated with $30 \mathrm{uM}$ curcumin and/or 1 UM ATRA for 48 hours. Controls were treated with $0.1 \%$ DMSO, $0.1 \%$ ethanol and/or the combination of both. Cells were then pulsed with BrdU overnight, fixed and followed by immunodetection of the incorporation of BrdU label. Absorbance was read at $450 \mathrm{~nm}$ to determine cell proliferation.

\section{Statistical analysis}

Statistical significance of differences between treatments was determined using two tailed student $t$-test and $\mathrm{p}$ values were noted. Differences between groups were considered statistically significant at $\mathrm{p}<0.05$. 


\section{Results}

Curcumin and ATRA suppress growth of RA-resistant TNBC cell lines

To examine the effect of curcumin and ATRA on cell viability, MTT assay was performed in two RA-resistant TNBC cell lines. Mammary carcinoma cell, MDA-MB-231 is sensitive to curcumin [59] and resistant to ATRA [60]. As shown in Figure 1A, curcumin suppresses mammary carcinoma cell growth of MDA-MB-231 cells in a dose dependent manner (Figure 1A). By 48 hours, $30 \mu \mathrm{M}$ curcumin alone had produced a growth inhibitory effect of approximately $40 \%$ in MDA-MB-231 cells. As illustrated in Figure 1B, the response to $30 \mu \mathrm{M}$ of curcumin to suppress cell proliferation of MDA-MB-231 cells is also time dependent (Figure 1B). Thus, the proliferation of MDA-MB-231 cells was inhibited by curcumin in a dose and time-dependent manner. To assess whether curcumin could sensitize these cells to RA-mediated growth suppression, we performed MTT assay in MDA-MB-231 cells treated with varying doses of curcumin in the presence or absence of $1 \mu \mathrm{M}$ ATRA. As expected, MDA-MB-231 cells treated only with ATRA were resistant to cell growth suppression while $10 \mu \mathrm{M}$ or $20 \mu \mathrm{M}$ curcumin suppressed growth, although not statistically significant (Figure 1C). The combination of ATRA with $10 \mu \mathrm{M}$ or $20 \mu \mathrm{M}$ of curcumin did not effect cell growth (Figure 1C). In fact, cell growth of MDA-MB-231 cells treated with curcumin and ATRA was similar to ATRA-treated cells, suggesting that the proliferative function of RA suppresses the antiproliferative effects of curcumin. As expected, $30 \mu \mathrm{M}$ curcumin suppressed mammary carcinoma cell growth by $40 \%$ (Figure 1d) and interestingly, MDA-MB-231 cells treated with a combination of $30 \mu \mathrm{M}$ curcumin and $1 \mu \mathrm{M}$ ATRA further reduced cell growth to approximately $60 \%$, sensitizing TNBC MDA-MB-231 cells to the inhibitory effects of RA (Figure 1d). At a maximal dose of $30 \mu \mathrm{M}$ curcumin, this agent was able to sensitize MDA-MB-231 cells to RA.

To test whether sensitivity to ATRA can be attained by treatment of another RA-resistant breast cancer cells with curcumin, we performed cell proliferation assay in TNBC MDA-MB-468 cells. The growth inhibitory effect of curcumin was observed in MDA-MB-468 cells (Figure 2a)
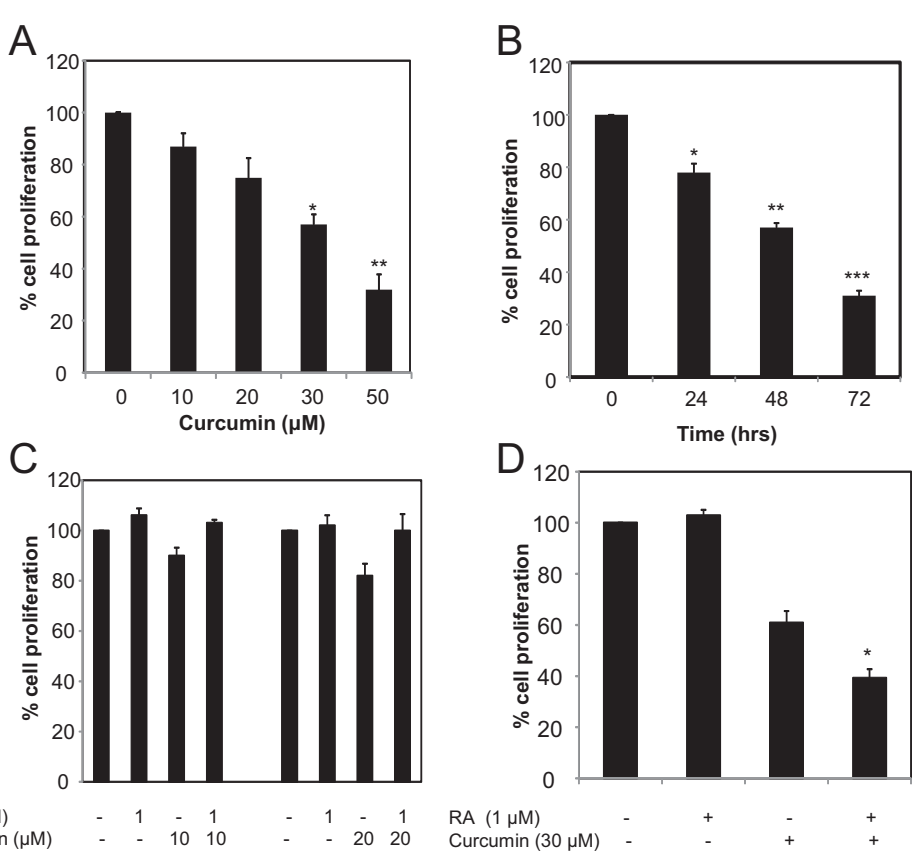

Figure 1 Curcumin sensitizes MDA-MB-231 cells to RA-mediated growth suppression. (A) MDA-MD-231 cells were treated with varying dose of curcumin for 48 hours. Control was DMSO. The \% cell proliferation for each of the treatment with curcumin for the designated concentration was calculated with respect to the treatment with DMSO. Data are mean of $\pm \mathrm{SE}(n=3)$. * $p=0.008$ versus control, ** $p=0.007$ versus control (B) MDA-MD-231 cells were treated with $30 \mu \mathrm{M}$ curcumin for varying time. Control was DMSO. The \% cell proliferation for each of the treatment with curcumin for the designated time was calculated with respect to the treatment with DMSO for the corresponding time. Data are mean of \pm SE $(n=3)$. ${ }^{*} p=0.0025$ versus control, ${ }^{* *} p=0.002$ versus control, ${ }^{* * *} p=0.0007$ versus control. (C) MDA-MB-231 cells were treated with $1 \mu M$ ATRA (RA), $10 \mu M$ or $20 \mu \mathrm{M}$ curcumin and the combination of both agents for 48 hours. Control was DMSO, ethanol or a combination of both. The \% cell proliferation for each of the treatment (curcumin, ATRA or both) was calculated relative to their solvent, DMSO, ethanol or DMSO and ethanol, respectively. The controls were set at 100\%. Data are mean of \pm SE $(n=3)$. (D) MDA-MB-231 cells were treated with $1 \mu M$ ATRA, $30 \mu M$ curcumin, or $30 \mu \mathrm{M}$ curcumin and $1 \mu \mathrm{M}$ ATRA for 48 hours. Control was DMSO, ethanol or a combination of both. The $\%$ cell proliferation for each of the treatment (curcumin, ATRA or both) was calculated relative to their solvent, DMSO, ethanol or DMSO and ethanol, respectively. The controls were set at $100 \%$. Data are mean of $\pm S E(n=4) .{ }^{*} p=0.000036$ versus curcumin treatment. 


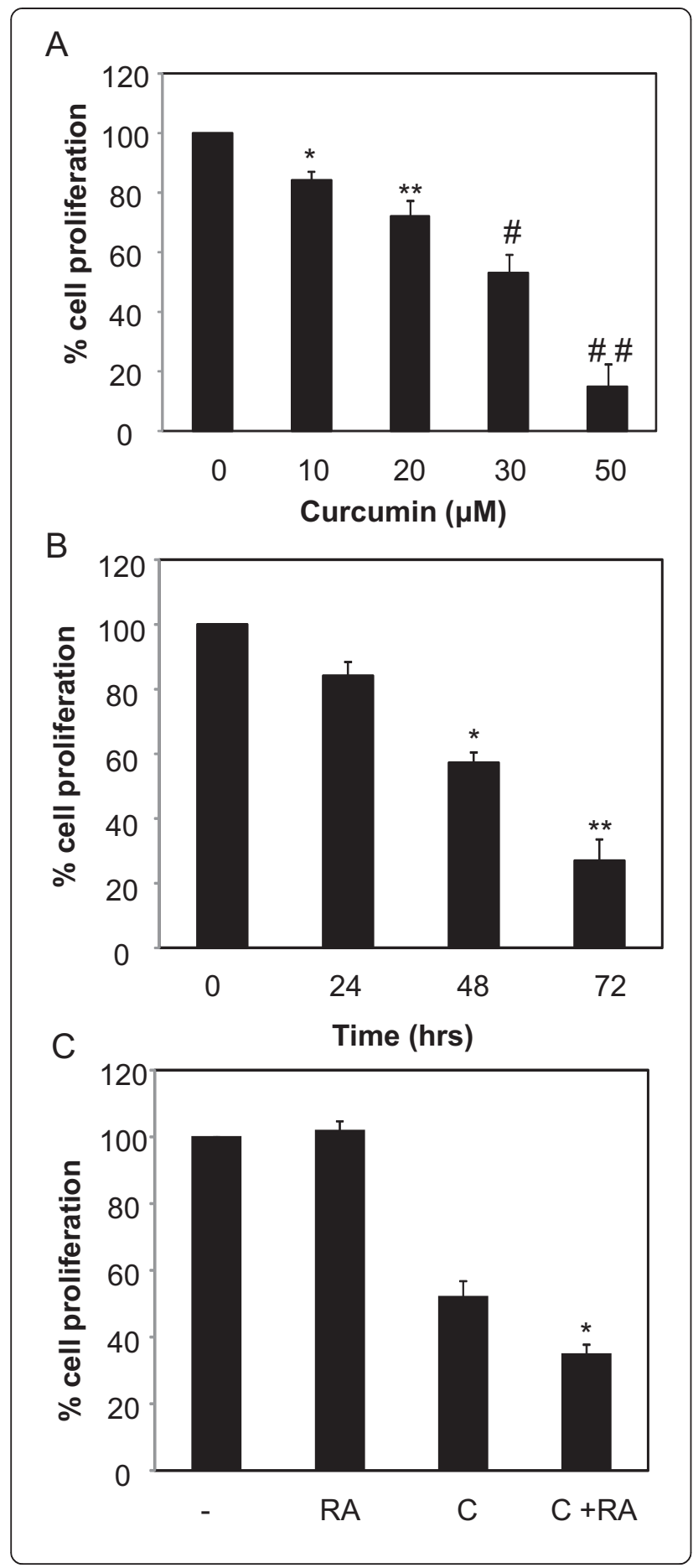

Figure 2 RA-resistant MDA-MB-468 cells are sensitized to ATRA by curcumin. (A) MDA-MD-468 cells were plated in 96 well plates, treated with varying dose of curcumin for 48 hours and the control used was DMSO. The \% cell proliferation for each of the treatment with curcumin for the designated concentration was calculated with respect to the treatment with DMSO for the corresponding dose. Data are mean of $\pm \mathrm{SE}(n=3) .{ }^{*} p=0.04$ versus control, ${ }^{* *} p=0.04$ versus control, \# $p=0.02$ versus control, \# \# $p=0.008$. (B) MDA-MD-468 cells were plated in 96 well plates, treated with $30 \mu \mathrm{M}$ curcumin for varying time. The control was DMSO treated according to the timeframe of the cells treated with curcumin. The \% cell proliferation for each of the treatment with curcumin for the designated time was calculated with respect to the treatment with DMSO for the corresponding time. Data are mean of $\pm S E(n=3) .{ }^{*} p=0.009$ versus control, ${ }^{* *} p=0.009$ versus control. (C) MDA-MB-468 cells (2500 cells/well) were plated in 96 well plates, treated with $1 \mu \mathrm{M}$ ATRA (RA), $30 \mu \mathrm{M}$ curcumin (C), or $30 \mu \mathrm{M}$ curcumin and $1 \mu \mathrm{M}$ ATRA for 48 hours. The control was DMSO, ethanol or a combination of both. The \% cell proliferation for each of the treatment (curcumin, ATRA or both) was calculated relative to their solvent, DMSO, ethanol or DMSO and ethanol, respectively. The controls were set at $100 \%$. Data are mean of $\pm S E(n=4) .{ }^{*} p=0.03$ versus curcumin.

and $30 \mu \mathrm{M}$ curcumin suppressed the proliferation of these cells in a time dependent manner (Figure 2b). Similar to the inhibitory effects of $30 \mu \mathrm{M}$ curcumin and $1 \mu \mathrm{M}$ ATRA in MDA-MB-231 cells (Figure 1d), we also observed similar results in MDA-MB-468. Curcumin reduced growth of MDA-MB-468, while no such inhibition was observed in the presence of ATRA (Figure 2c). However, the combination of both $1 \mu \mathrm{M}$ ATRA and $30 \mu \mathrm{M}$ curcumin reduced growth of MDA-MB-468 when compared to either treatment alone (Figure 2c). Thus, curcumin sensitizes RA-resistant TNBC cells to the growth suppressive effects of RA.

Curcumin down-regulates FABP5 and PPAR $\beta / \delta$ expression level in MDA-MB-231 and MDA-MB-468

Sensitivity to RA is dependent on the expression level of FABP5 in mammary carcinoma cells $[41,42,51,52]$. We examined the expression level of FABP5 in RA-resistant TNBC cell lines (MDA-MB-231 and MDA-MB-468) in comparison to mammary carcinoma cells sensitive to RA-mediated growth suppression. High mRNA expression level of FABP5 was evident in the highly aggressive, RA-resistant TNBC cell lines (Figure 3a), MDA-MB-231 and MDA-MB-468, which are both ER- and HER2- in comparison to MCF-7 (ER+/HER2-) and SkBr3 (ER-/ HER2+). Similarly, there is high FABP5 protein expression in MDA-MB-231 and MDA-MB-468 cell lines compared to MCF-7 and $\mathrm{SkBr} 3$ cells (Figure $3 \mathrm{~b}$ ). Although $\mathrm{SkBr} 3$ mammary carcinoma cells are aggressive and HER2+, these cells are sensitive to retinoic acid [61,62], as is MCF7 cells. It has been well established that FABP5 suppresses sensitivity of cancer cells to retinoic acid [41,51], and the fact that there is low expression level of FABP5 in SkBr3 suggests sensitivity of these cells to retinoic acid. Thus, a 


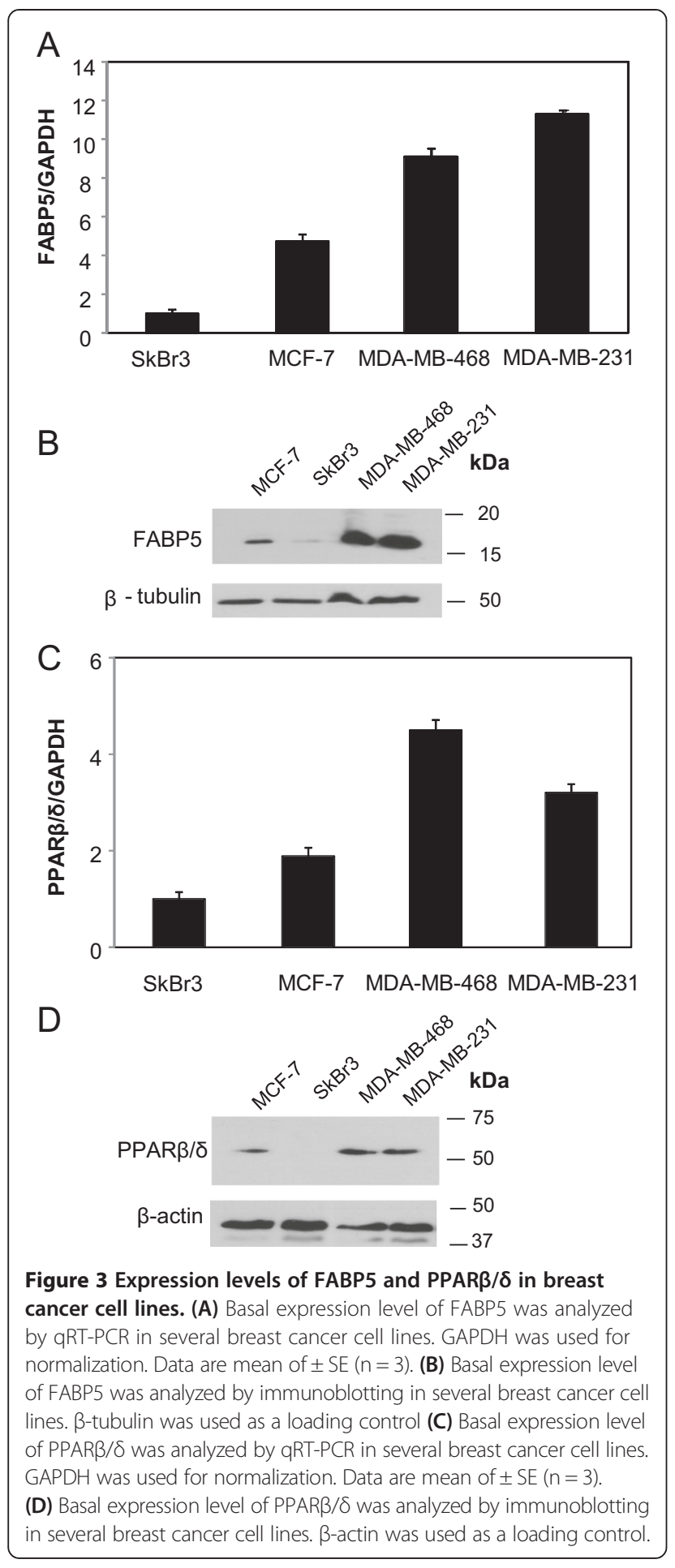

direct relationship exists between the high expression level of FABP5 and the lack of sensitivity to retinoic acid, and not the aggressiveness of the cancer.

The mRNA and protein expression of the nuclear receptor, $\operatorname{PPAR} \beta / \delta$ which binds to ligands delivered by FABP5 was also examined in the various breast cancer cell lines. High mRNA and protein expression level of
PPAR $\beta / \delta$ was evident in the RA-resistant mammary carcinoma cells, MDA-MB-231 and MDA-MB-468 (Figure 3c and d) when compared to MCF-7 cells. However, the highly aggressive SkBr3 had low levels of PPAR $\beta / \delta$ mRNA expression and undetectable levels of PPAR $\beta / \delta$ protein expression (Figure $3 \mathrm{c}$ and $\mathrm{d}$ ). This suggests there is no correlation between the level of PPAR $\beta / \delta$ and the aggressiveness of the breast cancer cells, but instead an association between RA-resistance and high expression of PPAR $\beta / \delta$.

As shown in Figure 1d, $30 \mu \mathrm{M}$ of curcumin suppressed RA- resistant MDA-MB-231 cells, while the combination with $1 \mu \mathrm{M}$ RA sensitized these cells to respond to retinoic acid-mediated growth suppression. To determine whether the enhanced growth-inhibitory effects of curcumin and RA on mammary carcinoma cells were likely due to associated changes of FABP5 expression, we sought to assess the effect of curcumin on FABP5 expression in MDA-MB-231 cells. To investigate whether curcumin regulates the expression level of FABP5, MDA-MB-231 cells were treated with varying concentrations of curcumin for 24 hours, and the levels of FABP5 protein were determined by Western blot analysis. Protein levels of FABP5 were reduced dose-dependently in MDA-MB-231 cells after treatment with curcumin (Figure 4a). A significant decrease in FABP5 protein expression was evident at $30 \mu \mathrm{M}$ curcumin (Figure 4a). The levels of FABP5 at mRNA level were also analyzed by qRT-PCR. To analyze the mRNA expression level of FABP5, MDA-MB-231 cells were treated with $30 \mu \mathrm{M}$ curcumin, mRNA isolated and consistent with reduced protein expression (Figure 4a), $30 \mu \mathrm{M}$ curcumin suppressed mRNA expression levels of FABP5 by approximately $30 \%$ (Figure $4 \mathrm{~b}$ ). At $30 \mu \mathrm{M}$ curcumin, FABP5 expression was reduced in MDA-MB-231 cells (Figure 4a, b), and at the same dose, curcumin sensitized them to RA-mediated growth suppression (Figure 1d).

It is known that FABP5 delivers ligands, such as RA, to the nuclear receptor PPAR $\beta / \delta[47,48]$, known to target genes involved in cell survival and proliferation. Since curcumin downregulates the expression of FABP5 (Figure 4a and $b$ ), we investigated the effect of curcumin on PPAR $\beta$ / $\delta$. MDA-MB-231 cells were treated with varying doses of curcumin and at $30 \mu \mathrm{M}$ of curcumin, a statistically significant decrease in $\mathrm{PPAR} \beta / \delta$ protein expression level was observed (Figure 4c), concomitant to the decrease of FABP5 expression by curcumin (Figure 4a and b). Suppression of $\mathrm{PPAR} \beta / \delta$ protein expression by curcumin was dose-dependent (Figure 4c). Since $30 \mu \mathrm{M}$ curcumin inhibited $\mathrm{PPAR} \beta / \delta$ protein expression, we also examined PPAR $\beta / \delta$ mRNA expression at this concentration. Our data shows that $30 \mu \mathrm{M}$ of curcumin reduced PPAR $\beta / \delta$ mRNA in these cells (Figure $4 \mathrm{~d}$ ). Because curcumin affects the expression level of FABP5 and PPAR $\beta / \delta$ in RA-resistant MDA-MB-231 mammary carcinoma cells, 

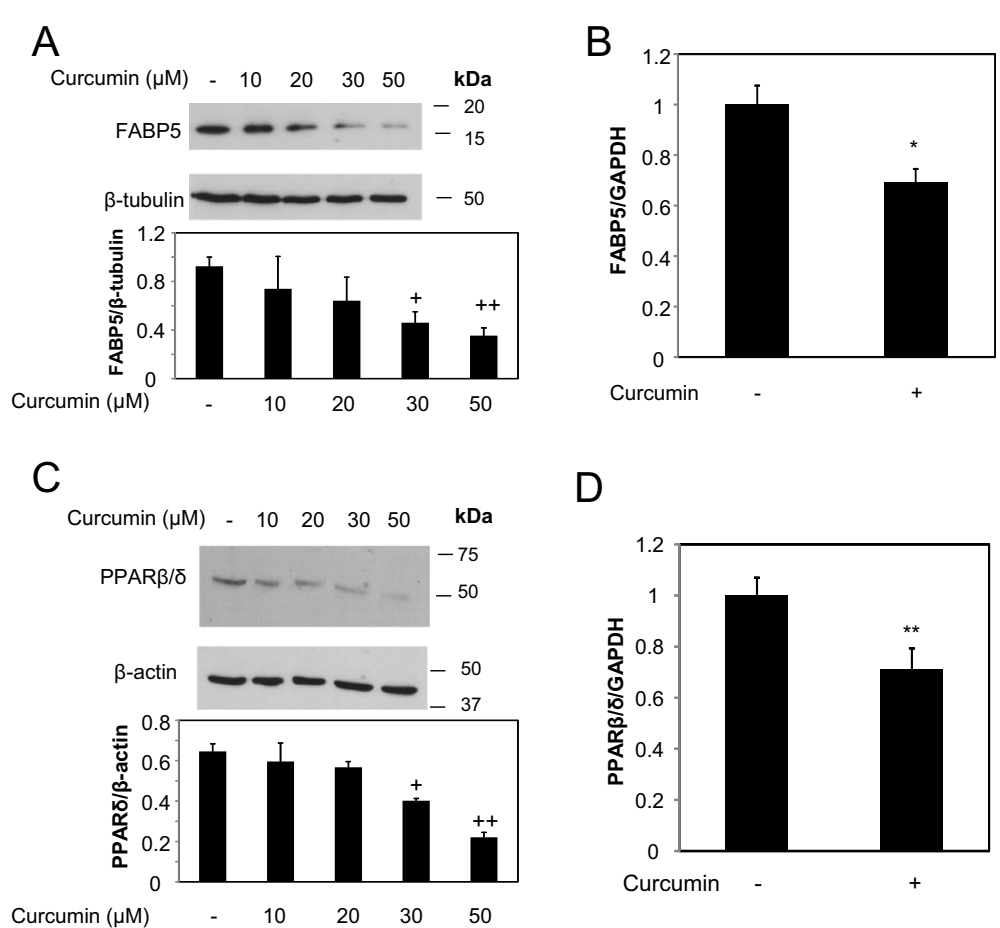

Figure 4 Curcumin suppresses the expression level of FABP5 and PPAR $\beta / \delta$ in MDA-MB-231 cells. (A) MDA-MB-231 cells were treated with varying concentration of curcumin for 24 hours (0.1\% DMSO was used for the control) prior to cell lysis. Cell lysates were resolved with SDS-PAGE and immunoblotted with antibodies recognizing FABP5, and $\beta$-tubulin was used as a loading control (top panel). Bottom panel: Densitometry analyses provide the relative amount of FABP5 normalized to $\beta$-tubulin. The analysis was performed in triplicates as mean of \pm SE.,$+ p=0.04$ versus control, ++ , $p=0.03$ versus control. (B) Total RNA was collected from MDA-MB-231 cells treated with curcumin $(30 \mu \mathrm{M})$ for 4 hours or $0.1 \%$ DMSO as control. Expression level of FABP5 was analyzed by qRT-PCR. GAPDH was used for normalization. Data are mean of $\pm S E(n=3)$. * $p=0.0002$ versus control treatment (C) MDA-MB-231 cells were treated with varying concentration of curcumin for 24 hours (0.1\% DMSO was used for the control) prior to cell lysis. Cell lysates were resolved with SDS-PAGE and immunoblotted with antibodies recognizing PPAR $/ \delta$, and $\beta$-actin was used as a loading control (top panel). Bottom panel: Densitometry analyses provide the relative amount of PPAR $\beta / \delta$ normalized to $\beta$-actin. The analysis was performed in triplicates as mean of \pm SE.,$+ p=0.04$ versus control,,$++ p=0.02$ versus control (D) Total RNA was collected from MDA-MB-231 cells treated with curcumin $(30 \mu \mathrm{M})$ for 4 hours or $0.1 \%$ DMSO as control. Expression level of PPARß/ $\delta$ was analyzed by qRT-PCR. GAPDH was used for normalization. Data are mean of $\pm \mathrm{SE}(n=3)^{* *} \mathrm{p}=0.0003$ versus control treatment.

we further examined the effect of curcumin on these genes in RA-resistant MDA-MB-468 cells. Curcumin reduced FABP5 protein expression in MDA-MB-468 cells in a dose dependent manner (Figure 5a), with a statistically significant reduction at $30 \mu \mathrm{M}$ of curcumin. Consistently, FABP5 mRNA expression was also reduced by $30 \mu \mathrm{M}$ of curcumin (Figure $5 \mathrm{~b}$ ). To examine the effect of curcumin on PPAR $\beta / \delta$ expression, we performed immunoblotting and qRT-PCR to determine the protein and mRNA expression of PPAR $\beta / \delta$, respectively. Curcumin suppressed PPAR $\beta / \delta$ protein expression in a dosedependent manner, with a statistically significant effect at $30 \mu \mathrm{M}$ of curcumin treatment (Figure 5c). Comparable results at the mRNA level of PPAR $\beta / \delta$ was also observed, wherein curcumin suppressed PPAR $\beta / \delta$ mRNA expression levels in MDA-MB-468 cells (Figure 5d).

\section{Regulation of FABP5 by curcumin is mediated by NF-KB} One of the established biological effects of curcumin to its chemopreventive activity is the inhibition of the NF- $\kappa B$ pathway [27]. Constitutive NF- $\kappa B$ activity is associated with enhanced proliferation and survival of malignant cells [63]. We sought to investigate whether the effect of curcumin on the expression level of FABP5 depends on NF- $\kappa B$, in particular since it has been described that this transcription factor regulates FABP5 through the two putative NF- $\kappa B$ response elements on the FABP5 promoter [56]. We assessed whether suppression of NF- $\mathrm{KB}$ by curcumin regulates the expression level of FABP5 in MDA-MB-231 cells. Equal amounts of cell lysates from control and $30 \mu \mathrm{M}$ curcumin-treated MDA-MB-231 cells were probed for the NF- $\mathrm{kB}$ subunit, p65 using western blot analysis. As reported previously [64] and as shown in Figure 6a, $30 \mu \mathrm{M}$ curcumin decreased p65 protein expression in MDA-MB-231 cells. To directly test the role of NF- $\mathrm{kB}$ to regulate FABP5 in MDA-MB-231 cells, we used pyrrolidine dithiocarbamate (PDTC), a chemical inhibitor on the activation of NF- $\mathrm{KB}$, to decrease p65 expression [65] and examined the effect of FABP5 protein expression. Treatment of MDA-MB-231 


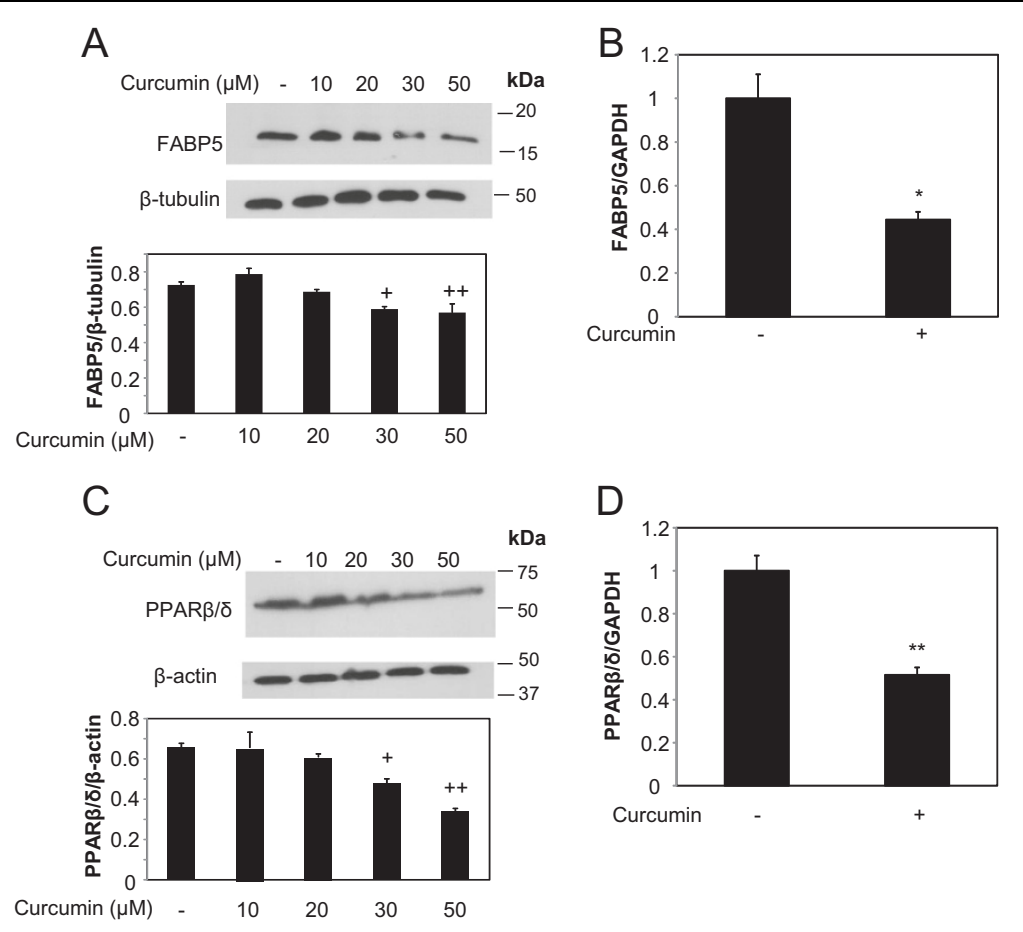

Figure 5 Curcumin suppresses the expression level of FABP5 and PPAR $\beta / \delta$ in MDA-MB-468 cells. (A) MDA-MB-468 cells were treated with $30 \mu \mathrm{M}$ of curcumin for 24 hours (0.1\% DMSO was used for the control) prior to cell lysis. Cell lysates were resolved with SDS-PAGE and immunoblotted with antibodies recognizing FABP5, and $\beta$-tubulin was used as a loading control. Bottom panel: Densitometry analyses provide the relative amount of FABP5 normalized to $\beta$-tubulin. The analysis was performed in triplicates as mean of $\pm S E .+, p=0.02$ versus control,,$++ p=0.04$ versus control (B) Total RNA was collected from MDA-MB-468 cells treated with curcumin $(30 \mu \mathrm{M})$ for 4 hours or $0.1 \%$ DMSO as control. Expression level of FABP5 was analyzed by qRT-PCR. GAPDH was used for normalization. Data are mean of $\pm \mathrm{SE}(n=3)$. ${ }^{*} p=0.03$ versus control treatment. (C) MDA-MB-468 cells were treated with varying concentration of curcumin for 24 hours (0.1\% DMSO was used for the control) prior to cell lysis. Cell lysates were resolved with SDS-PAGE and immunoblotted with antibodies recognizing PPAR $\beta / \delta$, and $\beta$-actin was used as a loading control (top panel). Bottom panel: Densitometry analyses provide the relative amount of PPAR $\beta / \delta$ normalized to $\beta$-actin. The analysis was performed in triplicates as mean of \pm SE.,$+ p=0.04$ versus control,,$++ p=0.007$ versus control. (D) Total RNA was collected from MDA-MB-468 cells treated with curcumin $(30 \mu \mathrm{M})$ for 4 hours or $0.1 \%$ DMSO as control. Expression level of PPAR $\beta / \delta$ was analyzed by qRT-PCR. GAPDH was used for normalization. Data are mean of $\pm \mathrm{SE}(n=3)^{* *} \mathrm{p}=0.03$ versus control treatment.

cells with $25 \mu \mathrm{M}$ PDTC suppressed p65 expression level at a modest level (Figure 6b). Concomitantly, we examined the protein expression level of FABP5 in MDA-MB-231 cells treated with PDTC and observed that suppression of the p65 subunit of NF- $\mathrm{kB}$ reduced FABP5 expression in MDA-MB-231 cells (Figure 6b). In addition, p65 was silenced in MDA-MB-231 cells and we examined the protein expression of FABP5 (Figure 6c). Knock-down of p65 suppressed FABP5 expression in these cells (Figure 6c). These results support our hypothesis that treatment with curcumin blocks the expression of NF$\kappa B$ regulated FABP5 gene expression, and that NF- $\kappa B$ is a regulator in the molecular mechanism of curcumin mediated suppression of FABP5.

Inhibition of PPAR $\beta / \delta$ target gene by curcumin and ATRA We assessed the population of cells using BrdU incorporation assay upon treatment with curcumin and/or ATRA in MDA-MB-231 cells. Mammary carcinoma cells were treated with either curcumin, ATRA or the combination of both agents for 48 hours and labeled with 5-bromo2-deoxyuridine (BrdU) overnight prior to analysis. As expected, treatment of MDA-MB-231 cells with ATRA did not reduce cell proliferation (Figure 7a). However, MDA-MB-231-treated with curcumin showed a reduction in the population of cells, noted by the reduction in BrdU incorporation, and the effect was pronounced when combined with ATRA (Figure 7a). Hence, curcumin and RA together suppress cell proliferation, supporting the results of the MTT assay (Figure 1d).

Activation of PPAR $\beta / \delta$ induces the transcriptional activity of several downstream genes in mammary carcinoma cells such as the survival factor PDK1/Akt, VEGF-A and 14-3-3-epsilon $[41,42,50]$. We examined the effect of curcumin and/or ATRA on the mRNA expression level of PDK1 in MDA-MB-231. As shown in Figure 7b, a 4-hour treatment of MDA-MB-231 cells with $1 \mu \mathrm{M}$ of ATRA enhanced the mRNA level of the survival factor, PDK1. Although RA enhanced survival factor, PDK1 mRNA expression within 4 hours, enhanced cell proliferation 


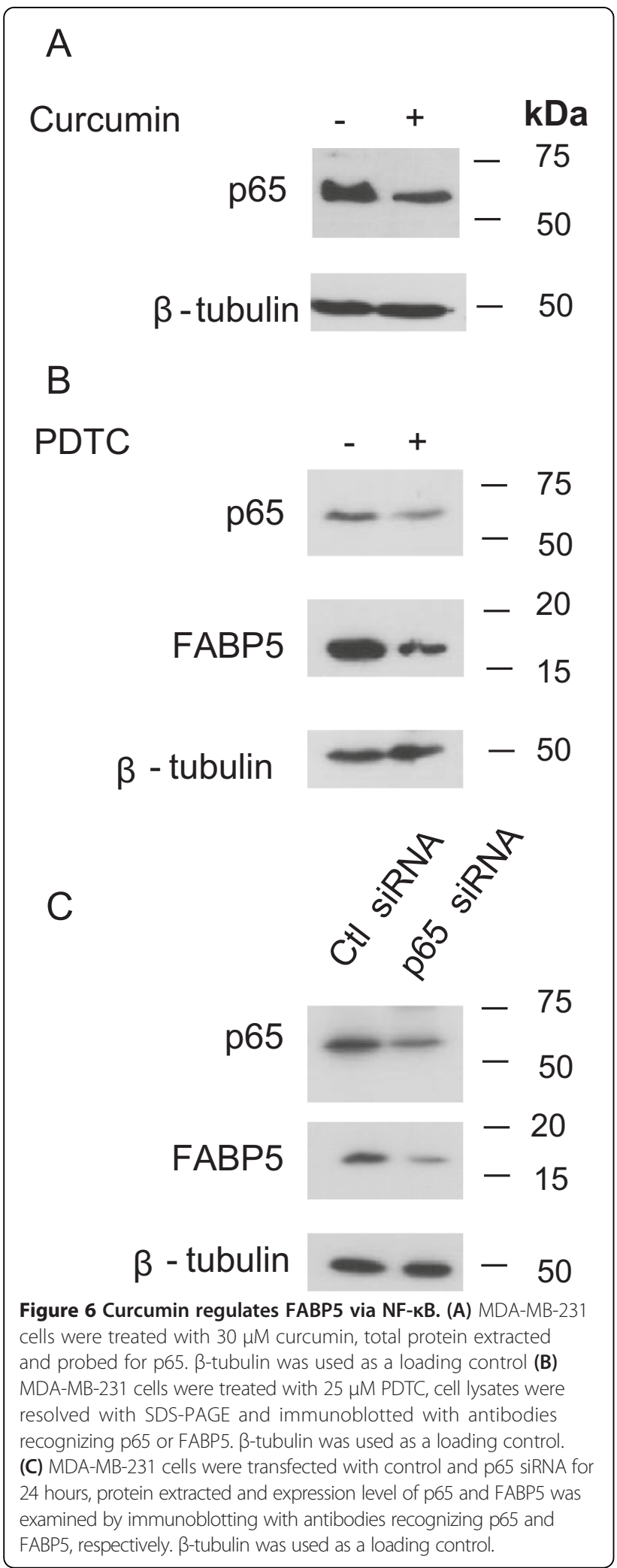

was not observed after 48 hours of treatment with RA and growth of the cells remained as that of the control cells (Figure 7a). The conventional growth inhibitory properties of RA in some cells [35,37-40,66] was not observed in triple negative breast cancer cell line, MDA-MB-231 but as noted previously [60] and as seen in Figures 1d and 7a, MDA-MB-231 cells are retinoic acid resistant. However in some carcinomas, RA enhances hyperproliferation [41,67-69]. To determine whether there is delayed response to hyperproliferation and PDK1 expression, MDA-MB-231were treated with $1 \mu \mathrm{M}$ ATRA for 2-8 days. At approximately 6 days, RA promoted hyperproliferation of MDA-MB-231 cells (Figure 7c). The timeframe at which PDK1 is induced does not correlate with the time at which MDA-MB-231 cells responds to RA with hyperproliferation, but these results demonstrate that these cells are resistant to the growth inhibitory effects of RA and thus RA-resistant. While ATRA enhanced PDK1 expression, a small reduction $(\sim 20 \%)$ in mRNA levels was observed when cells were treated with curcumin, though the effect was not statistically significant (Figure 7b). PPAR $\beta / \delta$ ligands have been shown to activate PDK1 expression in several cells $[41,42]$ but other reports suggest that PDK1 is not a direct target of PPAR $\beta / \delta$ $[70,71]$. In our study, we observed that despite the downregulation of PPAR $\beta / \delta$ by curcumin in MDA-MB-231 cells (Figure 4c, d), curcumin does not suppress PDK1 (Figure $7 \mathrm{~b}$ ), suggesting that PDK1 is not regulated by $\mathrm{PPAR} \beta / \delta$ in these cells (Figure $7 \mathrm{~b}$ ). However, the combination of curcumin and ATRA further reduced PDK1 at the mRNA level, compared to curcumin alone (Figure $7 \mathrm{~b}$ ). Although PDK1 may not be a PPAR $\beta / \delta$ target gene in these cells, we can conclude that RA regulates PDK1 mRNA expression by an alternative mechanism in these cells. Curcumin may regulate this mechanism and suppress the upregulation of PDK1 mRNA expression by RA.

Due to the controversy that remains on whether PDK1 is a direct target of $\operatorname{PPAR} \beta / \delta$, we also examined the effect of curcumin and RA on another PPAR $\beta / \delta$ target gene, VEGF-A [72]. As shown in Figure 7d, ATRA induced VEGF-A mRNA expression, while curcumin suppressed VEGF-A (Figure 7d). In addition, the combination of curcumin and RA further suppressed VEGF-A expression (Figure $7 d$ ). Curcumin-mediated suppression of $P P A R \beta / \delta$ in MDA-MB-231 cells, when compared to control, reduces the downstream target gene, VEGF-A by approximately $40 \%$, while curcumin suppressed RA-mediated transcriptional activity of PPAR $\beta / \delta$ target gene, VEGF-A by an additional $30 \%$. This suggests that the proliferative effect of RA in these cells is diminished in the combination with curcumin, owing to the fact that curcumin suppresses the FABP5/PPAR $\beta / \delta$ pathway, and MDA-MB-231 cells are sensitized to the growth inhibitory effects of RA.

\section{Discussion}

In this study, we show that curcumin sensitizes RAresistant TNBC cells to RA-mediated growth suppression 

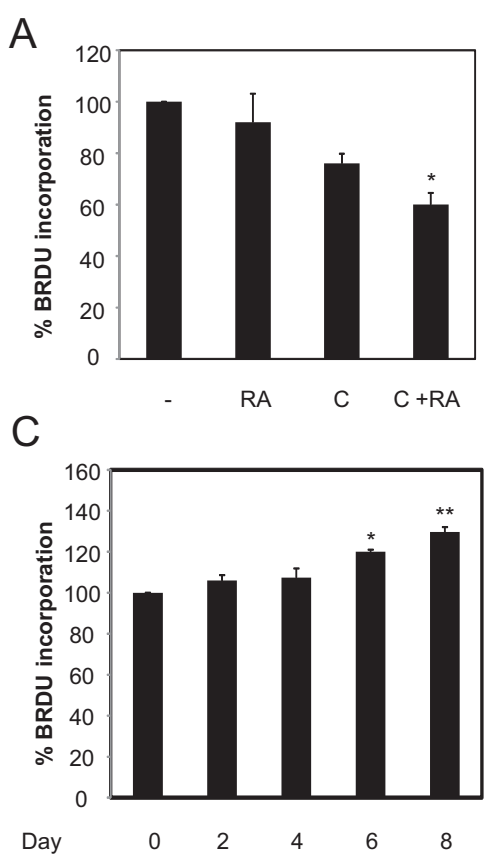

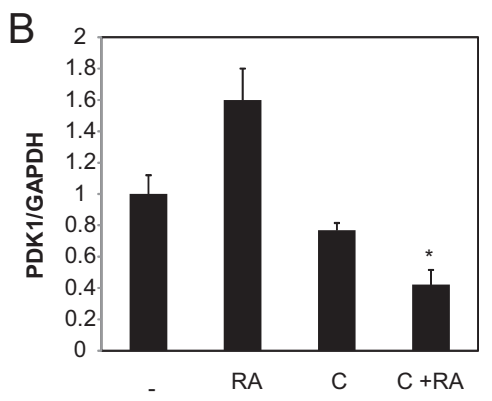

D

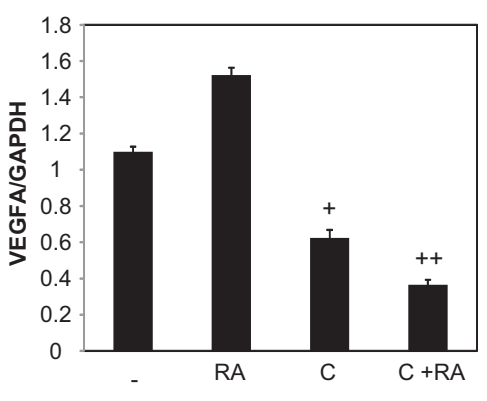

Figure 7 Curcumin and ATRA reduce VEGF-A expression in MDA-MB-231 cells. (A) MDA-MB-231 cells were plated in 96 well plates treated with $1 \mu \mathrm{M}$ ATRA (RA), $30 \mu \mathrm{M}$ curcumin (C) or $30 \mu \mathrm{M}$ curcumin and $1 \mu \mathrm{M}$ ATRA for 48 hours. The control was DMSO, ethanol or a combination of both. The \% BrdU incorporation for each of the treatment (curcumin, ATRA or both) was calculated relative to their solvent, DMSO, ethanol or DMSO and ethanol, respectively. Data are mean of $\pm \mathrm{SE}(n=3)$. ${ }^{*}, p=0.035$ versus curcumin. (B) MDA-MB-231 cells were treated with $30 \mu \mathrm{M}$ curcumin (C) for 24 hours prior to the addition of $1 \mu$ M ATRA (RA) for 4 hours. Total RNA was collected from MDA-MB-231, qRT-PCR was performed and expression levels of PDK1 were measured. GAPDH was used for normalization. Data are mean of $\pm S E(n=3)$. ${ }^{*}, p=0.012$ versus curcumin. (C) MDA-MB-231 cells were plated in 96 well plates treated with $1 \mu \mathrm{M}$ ATRA for 2-8 days. The \% BrdU incorporation for each of the treatment was calculated relative to their solvent, DMSO. Data are mean of $\pm \mathrm{SE}(n=3) .{ }^{*}, p=0.0008$ versus control ${ }^{* *} p=0.002$ versus control. (D) MDA-MB-231 cells were treated with $30 \mu \mathrm{M}$ curcumin (C) for 24 hours prior to the addition of $1 \mu \mathrm{M}$ ATRA (RA) for 4 hours. Total RNA was collected from MDA-MB-231, qRT-PCR was performed and expression levels of VEGF-A was measured. GAPDH was used for normalization. Data are mean of $\pm S E(n=3) .+, p=0.016$ versus control, ++ , $p=0.03$ versus curcumin.

by modulating the expression level of the FABP5/PPAR $\beta /$ $\delta$ pathway. The high expression level of FABP5 in the aggressive RA-resistant TNBC cells, MDA-MB-231 and MDA-MB-468, correlates with the marked upregulation of FABP5 observed in human breast tumors, particularly in tumors categorized by its invasive properties as well as late stages of breast cancer [51,52]. Our observation shows that curcumin downregulates FABP5 expression, and concomitantly suppresses its cognate receptor, $\operatorname{PPAR} \beta / \delta$. Adding to the network of genes regulated by curcumin [28], we demonstrate that curcumin regulates the pro-proliferative gene, FABP5 and the nuclear receptor, PPAR $\beta / \delta$.

Several PPAR $\beta / \delta$ target genes, such as PDK1 and VEGF-A are involved in proliferation and angiogenesis, respectively $[41,42,72]$. In mammary carcinoma cells expressing high levels of FABP5, FABP5 delivers RA to $\mathrm{PPAR} \beta / \delta$, enhances the transcriptional activity of PPAR $\beta /$ $\delta$ and activates PPAR $\beta / \delta$ target gene, PDK1 and VEGF-A $[41,42]$. Based on previous reports that RA regulates PDK1 through PPAR $\beta / \delta$, we also examined the regulation of PDK1 by RA in MDA-MB-231 cells. From our data, we conclude that RA regulates PDK1, however regulation of PDK 1 by RA is not via PPAR $\beta / \delta$ in these cells. Several studies have also demonstrated that PDK1 is not a PPAR $\beta / \delta$ target gene $[70,71]$. Comparing the suppression of PDK1 by curcumin and/or ATRA suggests that curcumin alone reduces PDK1 expression (not statistically significant), while the combination of the agents further suppress PDK1 mRNA expression. RA may be regulating PDK1, at the mRNA level, by an alternative mechanism. Hence, curcumin may regulate this mechanism and thereby suppress RA-mediated upregulation of PDK1 mRNA. Further studies will be required to dissect the pathway by which RA regulates PDK1 in these cells. Examining the effect of curcumin and ATRA on another PPAR $\beta / \delta$ target gene, VEGF-A, we discovered that RA enhances VEGF-A, while curcumin significantly decreases VEGF-A mRNA expression. Suppression of FABP5 by curcumin reduces the delivery of RA to PPAR $\beta / \delta$, resulting in diminished transcriptional activation of PPAR $\beta / \delta$ by ATRA. Curcumin suppresses VEGF-A expression by approximately $45 \%$, however in the combination of ATRA, mRNA expression of VEGF-A is reduced to an additional 
$30 \%$. Thus, downregulation of FABP5 by curcumin reduces delivery of ATRA to PPAR $\beta / \delta$, hence reducing RAmediated transcriptional activation of $\mathrm{PPAR} \beta / \delta$ target gene, VEGF-A.

Curcumin regulates multiple transcription factors, including NF- $\mathrm{kB}$. TNBC cells constitutively express NF$\mathrm{kB}$, a transcription factor that regulates genes known to be involved in proliferation, metastasis and angiogenesis [63]. Having shown previously that NF-kB regulates FABP5 [56], we demonstrate that the mechanism by which curcumin regulates FABP5 gene expression is mediated through the suppression of NF- $\mathrm{kB}$. Hence, FABP5 is regulated by NF- $\kappa B$ in mammary carcinoma MDA-MB-231 cells and curcumin downregulates FABP5 expression by suppressing the $\mathrm{p} 65$ subunit of NF- $\mathrm{kB}$.

Limited therapeutic options and poor prognosis of TNBC patients after the treatment with standard conventional drugs creates an emerging need to understand the molecular basis of this disease, as well as to identify alternative chemotherapeutic targets and treatments. A correlation with RA resistance in breast cancer tumors has been attributed to the high expression level of FABP5 [41,42,52] which has been associated with poor prognosis in cancer [51]. The fact that TNBC cell lines, MDA-MB-231 and MDA-MB-468, express high levels of FABP5 and are resistant to retinoid therapy suggests that by suppressing the expression level of FABP5, these subtypes of breast cancer cells can overcome RA resistance. Interestingly, our data show that downregulation of the FABP5/PPAR $\beta / \delta$ pathway by curcumin restores the sensitivity of RA-resistant TNBC cells to the inhibitory effects of RA and suppresses cell growth in the combination of curcumin and ATRA. Although a dose of $30 \mu \mathrm{M}$ curcumin is required to reduce cell growth of MDA-MB231 cells, it is at this dose that curcumin suppresses the FABP5/PPAR $\beta / \delta$ pathway. Hence, combining ATRA with $30 \mu \mathrm{M}$ curcumin reduces proliferation an additional $20 \%$ and chemosensitizes TNBCs to retinoid therapy. A marginal decrease in cell proliferation by the combination of curcumin and retinoic acid is consistent with the modest suppression of the FABP5/PPAR $\beta / \delta$ pathway. As shown in a previous study, that despite a modest reduction in breast cancer cell proliferation, the combination of metformin and hyperthermia translated to a significant reduction in colony sphere formation [73]. Similarly, synthetic analogues of curcumin, CDF reversed the resistance of pancreatic cells to gemcitabine [74]. Although a $10-20 \%$ reduction in cell proliferation was observed in the combination of the two drugs in comparison to CDF alone, the growth inhibitory effects of the combined drugs resulted in significant reduction in colony formation. Despite the modest reduction in our study on mammary carcinoma cell growth with the combination of curcumin and ATRA, this study may translate to a more significant effect in vivo. Future studies will explore the effect of curcumin and retinoic acid on the transformational properties of cancer cells to provide information for its use in in vivo studies.

Breast cancer cells respond to curcumin at $1-50 \mu \mathrm{M}$ range with the strongest effect between 20-30 $\mu \mathrm{M}$ [15] . Consistent with our data, several reports have documented that $30 \mu \mathrm{M}$ curcumin suppresses MDA-MB-231 mammary carcinoma cell growth within the time frame of 48 hours by approximately 40-50\% [59,75-77]. Curcumin has also been studied in several cancer models such as colorectal carcinoma, non small cell lung cancer and pancreatic cancer, and depending on the cancer model, the $\mathrm{IC}_{50}$ of curcumin has not only varied among the different cancers, but also between subtypes within a cancer model [78]. One of the criteria that determines the degree to which curcumin can suppress cell proliferation is dependent on the uptake of curcumin within the cells. For instance, MDA-MB-231 cells were more sensitive to the anti-proliferative activity of $25-50 \mu \mathrm{M}$ curcumin compared to MCF-7 cells [79]. The cellular uptake of curcuminoids in breast cancer cells correlated with the inhibitory activity of this compound which is a determinant of the $\mathrm{IC}_{50}$ of curcuminoids in the cancer subtype [79]. Despite the differences in the $\mathrm{IC}_{50}$ among cancer cells, one of the advantages of curcumin is its preferential uptake by tumor cells compared to normal cells [80]. Among the strategies used to improve the efficacy of curcumin and potentiate the growth-inhibitory activity of this agent, and more importantly reversing chemoresistance in cancer models, has been aimed at designing and synthesizing novel structural analogues of curcumin [81]. One such compound is demethoxycurcumin which has the potential of suppressing a wide range of mammary carcinoma cell lines with the most efficient inhibitory activity on TNBC (MDA-MB-231 and BT-20) [82]. Analogues of curcumin, such as HO-3867 are taken up by multiple drug resistant or sensitive cancer cell lines at considerably lower doses than curcumin [83], while synthetic analogues, G0-Y030, FLLL-11 and FLLL-12 promotes anti-proliferation in colorectal cancer cells at lower $\mathrm{IC}_{50}$ than curcumin [81]. The safety and tolerance of curcumin has been demonstrated in several clinical trials [84], however the disadvantage of curcumin is its poor absorption properties [22]. One such study has shown the improvement in the reduction of cell growth and colony formation of colon cancer stem cells upon treatment with curcumin analog, CDF with 5-fluorouracil and oxaliplatin compared to 5-FU and oxaliplatin with free curcumin [85]. To prevent the emergence on the chemoresistance of cancer cells to conventional chemotherapeutic agents, several studies have employed the use of curcumin to sensitize cancer cells to chemotherapeutic drugs, such as doxorubicin [86]. By improving 
the absorption of curcumin and cellular uptake of curcumin, curcumin derivatives may be more potent in suppressing the FABP5/PPAR $\beta / \delta$ pathway, and enhance the efficacy of RA by reducing the dosage to be used in vivo, in order to better tolerate its use in cancer patients.

Mounting evidence has demonstrated that the expression level of FABP5 is low in low grade tumors and highly upregulated as the progression of the disease manifests to aggressive, metastatic tumors [51,52,87-89], clarifying the importance of a rational drug design targeting FABP5. Identifying potential drug targets against FABP5 will establish the sensitivity of cancer cells to RA and may prove to be a rationale to improve the clinical outcome of RA use in breast cancer patients. Our studies demonstrate that curcumin can be used to overcome RA resistance in mammary carcinoma cells since curcumin suppresses FABP5 expression level, reducing the delivery of RA to $\operatorname{PPAR} \beta / \delta$ and downregulating the expression of PPAR $\beta / \delta$ target gene. To overcome the challenges of using free curcumin, novel structural analogs of curcumin have been synthesized to improve the chemotherapeutic effects $[22,23]$. In addition, curcumin encapsulated in liposomes or production of curcumin nanoparticles has been formulated to enhance the selective delivery of these drugs [90-92]. Using various derivatives of curcumin would improve bioavailability which may improve treatment of breast cancer with RA.

Taken together, we have shown that curcumin in combination with RA sensitizes RA-resistant TNBC cells by suppressing FABP5/PPAR $\beta / \delta$ pathway, and promotes the growth inhibitory effect of RA. Knowing that the acquired resistance to RA in TNBC cells is manifested by the increased expression of FABP5, future studies will entail the development of inhibitors against FABP5. Moreover, we provide evidence that curcumin can inhibit FABP5 and the use of curcumin or its analogs may serve as potential therapeutic agents to overcome RA resistance in RA-resistant breast cancer cells.

\section{Conclusions}

The results of this study showed that curcumin sensitizes RA-resistant TNBC cells to RA-mediated growth suppression. By suppressing the expression level of FABP5 and its cognate receptor, $P P A R \beta / \delta$, curcumin suppresses the downstream target gene of PPAR $\beta / \delta$, VEGF-A. The inhibitory effects of curcumin on the FABP $5 /$ PPAR $\beta / \delta$ pathway reduce RA-induced VEGF-A expression. The mechanism by which curcumin regulates FABP5 is by downregulating the transcription factor, NF- $\mathrm{kB}$. Further investigation using analogs of curcumin or liposome based curcumin should be employed to evaluate the use of this drug to further enhance efficacy of RA and promote RA sensitivity in RA-resistant breast cancers.

\section{Abbreviations}

FABP5: Fatty acid-binding protein 5; TNBC: Triple negative breast cancer cell; NF-KB: Nuclear factor-kappa B; RA: Retinoic acid; RAR: Retinoic acid receptor; ATRA: All-trans-retinoic acid; RARE: Retinoic acid response element; PPAR $\beta / \delta$ : Peroxisome proliferator-activated receptor $\beta / \delta$; VEGF-A: Vascular endothelial growth factor A; DMSO: Dimethyl sulfoxide; MTT: 3-(4, 5-dimethylthiazol-2-yl)-2, 5-diphenyltetrazolium bromide; qRT-PCR: Quantitative Real-Time Polymerase Chain Reaction; PDTC: Pyrrolidine dithiocarbamate; BrdU: 5-bromo-2'-deoxyuridine.

\section{Competing interests}

The authors declare that they have no competing interests.

\section{Author's contributions}

PT contributed to the performance of experiments, data analysis and interpretation, and writing. DJM and IQM performed the experiments, collected the data and participated in the data analysis. All authors read and approved the final manuscript.

\section{Acknowledgements}

This work was supported by the start up funds from the College of Allied Health Professions at University of South Alabama. We thank Dr. William Gerthoffer at the Department of Biochemistry, University of South Alabama for access to the BIORAD quantitative real-time PCR machine. We also acknowledge the Department of Pharmacology, University of South Alabama for use of their film developer.

Received: 16 January 2014 Accepted: 16 September 2014

Published: 27 September 2014

\section{References}

1. Ripperger T, Gadzicki D, Meindl A, Schlegelberger B: Breast cancer susceptibility: current knowledge and implications for genetic counselling. Eur J Hum Genet 2009, 17(6):722-731.

2. Brouckaert $\mathrm{O}$, Wildiers $\mathrm{H}$, Floris $\mathrm{G}$, Neven P: Update on triple-negative breast cancer: prognosis and management strategies. Int J Womens Health 2012, 4:511-520.

3. Bayraktar S, Gluck S: Molecularly targeted therapies for metastatic triple-negative breast cancer. Breast Cancer Res Treat 2013, 138(1):21-35.

4. Chiorean R, Braicu C, Berindan-Neagoe I: Another review on triple negative breast cancer. Are we on the right way towards the exit from the labyrinth? Breast 2013, 22(6):1026-1033.

5. Engebraaten O, Vollan HK, Borresen-Dale AL: Triple-negative breast cancer and the need for new therapeutic targets. Am J Pathol 2013, 183(4):1064-1074.

6. den Hollander P, Savage MI, Brown PH: Targeted Therapy for Breast Cancer Prevention. Front Oncol 2013, 3:250.

7. Ali R, Mirza Z, Ashraf GM, Kamal MA, Ansari SA, Damanhouri GA, Abuzenadah AM, Chaudhary AG, Sheikh IA: New anticancer agents: recent developments in tumor therapy. Anticancer Res 2012, 32(7):2999-3005.

8. Hemalswarya S, Doble M: Potential synergism of natural products in the treatment of cancer. Phytother Res 2006, 20(4):239-249.

9. Rajput S, Mandal M: Antitumor promoting potential of selected phytochemicals derived from spices: a review. Eur J Cancer Prev 2012, 21(2):205-215

10. Gupta SC, Kismali G, Aggarwal BB: Curcumin, a component of turmeric: from farm to pharmacy. Biofactors 2013, 39(1):2-13.

11. Gupta SC, Patchva S, Aggarwal BB: Therapeutic roles of curcumin: lessons learned from clinical trials. AAPS J 2013, 15(1):195-218

12. Goel A, Aggarwal BB: Curcumin, the golden spice from Indian saffron, is a chemosensitizer and radiosensitizer for tumors and chemoprotector and radioprotector for normal organs. Nutr Cancer 2010, 62(7):919-930.

13. Shishodia S, Chaturvedi MM, Aggarwal BB: Role of curcumin in cancer therapy. Curr Probl Cancer 2007, 31(4):243-305.

14. Arbiser JL, Klauber N, Rohan R, van Leeuwen R, Huang MT, Fisher C, Flynn E, Byers HR: Curcumin is an in vivo inhibitor of angiogenesis. Mol Med 1998, 4(6):376-383.

15. Shao ZM, Shen ZZ, Liu CH, Sartippour MR, Go VL, Heber D, Nguyen M: Curcumin exerts multiple suppressive effects on human breast carcinoma cells. Int J Cancer 2002, 98(2):234-240.

16. Aggarwal BB, Sundaram C, Malani N, Ichikawa H: Curcumin: the Indian solid gold. Adv Exp Med Biol 2007, 595:1-75 
17. Carroll RE, Benya RV, Turgeon DK, Vareed S, Neuman M, Rodriguez L, Kakarala M, Carpenter PM, McLaren C, Meyskens FL Jr, Brenner DE: Phase Ila clinical trial of curcumin for the prevention of colorectal neoplasia. Cancer Prev Res (Phila) 2011, 4(3):354-364.

18. Dhillon N, Aggarwal BB, Newman RA, Wolff RA, Kunnumakkara AB, Abbruzzese $J$, Ng CS, Badmaev V, Kurzrock R: Phase II trial of curcumin in patients with advanced pancreatic cancer. Clin Cancer Res 2008, 14(14):4491-4499.

19. Lev-Ari S, Strier L, Kazanov D, Madar-Shapiro L, Dvory-Sobol H, Pinchuk I, Marian B, Lichtenberg D, Arber N: Celecoxib and curcumin synergistically inhibit the growth of colorectal cancer cells. Clin Cancer Res 2005, 11(18):6738-6744

20. Notarbartolo M, Poma P, Perri D, Dusonchet L, Cervello M, D'Alessandro N: Antitumor effects of curcumin, alone or in combination with cisplatin or doxorubicin, on human hepatic cancer cells. Analysis of their possible relationship to changes in NF-kB activation levels and in IAP gene expression. Cancer Lett 2005, 224(1):53-65.

21. Majumdar AP, Banerjee S, Nautiyal J, Patel BB, Patel V, Du J, Yu Y, Elliott AA Levi E, Sarkar FH: Curcumin synergizes with resveratrol to inhibit colon cancer. Nutr Cancer 2009, 61(4):544-553.

22. Liang G, Yang S, Zhou H, Shao L, Huang K, Xiao J, Huang Z, Li X: Synthesis, crystal structure and anti-inflammatory properties of curcumin analogues. Eur J Med Chem 2009, 44(2):915-919.

23. Vyas A, Dandawate P, Padhye S, Ahmad A, Sarkar F: Perspectives on new synthetic curcumin analogs and their potential anticancer properties. Curr Pharm Des 2013, 19(11):2047-2069.

24. Yu LL, Wu JG, Dai N, Yu HG, Si JM: Curcumin reverses chemoresistance of human gastric cancer cells by downregulating the NF-kappaB transcription factor. Oncol Rep 2011, 26(5):1197-1203.

25. Vinod BS, Antony J, Nair HH, Puliyappadamba VT, Saikia M, Narayanan SS, Bevin A, Anto RJ: Mechanistic evaluation of the signaling events regulating curcumin-mediated chemosensitization of breast cancer cells to 5-fluorouracil. Cell Death Dis 2013, 4:e505.

26. Nessa MU, Beale P, Chan C, Yu JQ, Huq F: Studies on combination of platinum drugs cisplatin and oxaliplatin with phytochemicals anethole and curcumin in ovarian tumour models. Anticancer Res 2012, 32(11):4843-4850.

27. Shishodia S, Singh T, Chaturvedi MM: Modulation of transcription factors by curcumin. Adv Exp Med Biol 2007, 595:127-148.

28. Shehzad A, Lee J, Lee YS: Curcumin in various cancers. Biofactors 2013, 39(1):56-68.

29. Fields AL, Soprano DR, Soprano KJ: Retinoids in biological control and cancer. J Cell Biochem 2007, 102(4):886-898.

30. Evans TR, Kaye SB: Retinoids: present role and future potential. Br J Cancer 1999, 80(1-2):1-8.

31. Bushue N, Wan YJ: Retinoid pathway and cancer therapeutics. Adv Drug Deliv Rev 2010, 62(13):1285-1298.

32. Chambon P: A decade of molecular biology of retinoic acid receptors. FASEB J 1996, 10(9):940-954.

33. Germain P, Chambon P, Eichele G, Evans RM, Lazar MA, Leid M, De Lera AR, Lotan R, Mangelsdorf DJ, Gronemeyer H: International Union of Pharmacology. LXIII. Retinoid X receptors. Pharmacol Rev 2006, 58(4):760-772.

34. Schrader M, Wyss A, Sturzenbecker LJ, Grippo JF, LeMotte P, Carlberg C: RXR-dependent and RXR-independent transactivation by retinoic acid receptors. Nucleic Acids Res 1993, 21(5):1231-1237.

35. Park DJ, Chumakov AM, Vuong PT, Chih DY, Gombart AF, Miller WH Jr, Koeffler HP: CCAAT/enhancer binding protein epsilon is a potential retinoid target gene in acute promyelocytic leukemia treatment. J Clin Invest 1999, 103(10):1399-1408.

36. Koeffler HP: Is there a role for differentiating therapy in non-APL AML? Best Pract Res Clin Haematol 2010, 23(4):503-508.

37. Donato $L$, Suh $J \mathrm{H}$, Noy $\mathrm{N}$ : Suppression of mammary carcinoma cell growth by retinoic acid: the cell cycle control gene Btg2 is a direct target for retinoic acid receptor signaling. Cancer Res 2007, 67(2):609-615.

38. Altucci L, Rossin A, Raffelsberger W, Reitmair A, Chomienne C, Gronemeyer H: Retinoic acid-induced apoptosis in leukemia cells is mediated by paracrine action of tumor-selective death ligand TRAIL. Nat Med 2001, 7(6):680-686.

39. Donato $\sqcup$, Noy $\mathrm{N}$ : Suppression of mammary carcinoma growth by retinoic acid: proapoptotic genes are targets for retinoic acid receptor and cellular retinoic acid-binding protein II signaling. Cancer Res 2005, 65(18):8193-8199.

40. Kitareewan S, Pitha-Rowe I, Sekula D, Lowrey CH, Nemeth MJ, Golub TR, Freemantle SJ, Dmitrovsky E: UBE1L is a retinoid target that triggers PML/
RARalpha degradation and apoptosis in acute promyelocytic leukemia. Proc Natl Acad Sci U S A 2002, 99(6):3806-3811.

41. Schug TT, Berry DC, Shaw NS, Travis SN, Noy N: Opposing effects of retinoic acid on cell growth result from alternate activation of two different nuclear receptors. Cell 2007, 129(4):723-733.

42. Schug TT, Berry DC, Toshkov IA, Cheng L, Nikitin AY, Noy N: Overcoming retinoic acid-resistance of mammary carcinomas by diverting retinoic acid from PPARbeta/delta to RAR. Proc Natl Acad Sci U S A 2008, 105(21):7546-7551.

43. Henion PD, Weston JA: Retinoic acid selectively promotes the survival and proliferation of neurogenic precursors in cultured neural crest cell populations. Dev Biol 1994, 161(1):243-250.

44. Jacobs S, Lie DC, DeCicco KL, Shi Y, DeLuca LM, Gage FH, Evans RM: Retinoic acid is required early during adult neurogenesis in the dentate gyrus. Proc Natl Acad Sci U S A 2006, 103(10):3902-3907.

45. Plum LA, Parada LF, Tsoulfas P, Clagett-Dame M: Retinoic acid combined with neurotrophin-3 enhances the survival and neurite outgrowth of embryonic sympathetic neurons. Exp Biol Med (Maywood) 2001, 226(8):766-775.

46. Rodriguez-Tebar A, Rohrer H: Retinoic acid induces NGF-dependent survival response and high-affinity NGF receptors in immature chick sympathetic neurons. Development 1991, 112(3):813-820.

47. Tan NS, Shaw NS, Vinckenbosch N, Liu P, Yasmin R, Desvergne B, Wahli W, Noy N: Selective cooperation between fatty acid binding proteins and peroxisome proliferator-activated receptors in regulating transcription. Mol Cell Biol 2002, 22(14):5114-5127.

48. Di-Poi N, Tan NS, Michalik L, Wahli W, Desvergne B: Antiapoptotic role of PPARbeta in keratinocytes via transcriptional control of the Akt1 signaling pathway. Mol Cell 2002, 10(4):721-733.

49. Peters JM, Foreman JE, Gonzalez FJ: Dissecting the role of peroxisome proliferator-activated receptor-beta/delta (PPARbeta/delta) in colon, breast, and lung carcinogenesis. Cancer Metastasis Rev 2011, 30(3-4):619-640.

50. Brunelli L, Cieslik KA, Alcorn JL, Vatta M, Baldini A: Peroxisome proliferatoractivated receptor-delta upregulates 14-3-3 epsilon in human endothelial cells via CCAAT/enhancer binding protein-beta. Circ Res 2007, 100(5):e59-71.

51. Liu RZ, Graham K, Glubrecht DD, Germain DR, Mackey JR, Godbout R: Association of FABP5 expression with poor survival in triple-negative breast cancer: implication for retinoic acid therapy. Am J Pathol 2011, 178(3):997-1008

52. Levi L, Lobo G, Doud MK, von Lintig J, Seachrist D, Tochtrop GP, Noy N: Genetic ablation of the fatty acid-binding protein FABP5 suppresses HER2-induced mammary tumorigenesis. Cancer Res 2013, 73(15):4770-4780.

53. Gupta S, Pramanik D, Mukherjee R, Campbell NR, Elumalai S, de Wilde RF, Hong SM, Goggins MG, De Jesus-Acosta A, Laheru D, Maitra A: Molecular determinants of retinoic acid sensitivity in pancreatic cancer. Clin Cancer Res 2012, 18(1):280-289.

54. Barbus S, Tews B, Karra D, Hahn M, Radlwimmer B, Delhomme N, Hartmann C, Felsberg J, Krex D, Schackert G, Martinez R, Reifenberger G, Lichter P: Differential retinoic acid signaling in tumors of long- and short-term glioblastoma survivors. J Natl Cancer Inst 2011, 103(7):598-606.

55. Morgan E, Kannan-Thulasiraman P, Noy N: Involvement of Fatty Acid Binding Protein 5 and PPARbeta/delta in Prostate Cancer Cell Growth. PPAR Res 2010, 2010:9 pages. Article ID 234629.

56. Kannan-Thulasiraman P, Seachrist DD, Mahabeleshwar GH, Jain MK, Noy N: Fatty acid-binding protein 5 and PPARbeta/delta are critical mediators of epidermal growth factor receptor-induced carcinoma cell growth. J Biol Chem 2010, 285(25):19106-19115.

57. Adhikary T, Brandt DT, Kaddatz K, Stockert J, Naruhn S, Meissner W Finkernagel F, Obert J, Lieber S, Scharfe M, Jarek M, Toth PM, Scheer F, Diederich WE, Reinartz S, Grosse R, Müller-Brüsselbach S, Müller R: Inverse PPARbeta/delta agonists suppress oncogenic signaling to the ANGPTL4 gene and inhibit cancer cell invasion. Oncogene 2013, 32(44):5241-5252.

58. Choi JM, Devkota S, Sung YH, Lee HW: El24 regulates epithelial-tomesenchymal transition and tumor progression by suppressing TRAF2-mediated NF-kappaB activity. Oncotarget 2013, 4(12):2383-2396.

59. Palange AL, Di Mascolo D, Singh J, De Franceschi MS, Carallo C, Gnasso A, Decuzzi P: Modulating the vascular behavior of metastatic breast cancer cells by curcumin treatment. Front Oncol 2012, 2:161.

60. van der Burg B, van der Leede BM, Kwakkenbos-Isbrucker L, Salverda S, de Laat SW, van der Saag PT: Retinoic acid resistance of estradiol-independent breast cancer cells coincides with diminished retinoic acid receptor function. Mol Cell Endocrinol 1993, 91(1-2):149-157. 
61. Berardi DE, Bessone MI, Motter A, de Kier Joffe ED B, Urtreger AJ, Todaro LB: Involvement of protein kinase $C$ alpha and delta activities on the induction of the retinoic acid system in mammary cancer cells. Mol Carcinog 2014, doi:10.1002/mc.22181.

62. Grunt Th W, Dittrich E, Offterdinger M, Schneider SM, Dittrich C, Huber H: Effects of retinoic acid and fenretinide on the c-erbB-2 expression, growth and cisplatin sensitivity of breast cancer cells. Br J Cancer 1998, 78(1):79-87.

63. Biswas DK, Shi Q, Baily S, Strickland I, Ghosh S, Pardee AB, Iglehart JD: NF-kappa B activation in human breast cancer specimens and its role in cell proliferation and apoptosis. Proc Natl Acad Sci U S A 2004 101(27):10137-10142.

64. Kim SR, Park HJ, Bae YH, Ahn SC, Wee HJ, Yun I, Jang HO, Bae MK, Bae SK: Curcumin down-regulates visfatin expression and inhibits breast cancer cell invasion. Endocrinology 2012, 153(2):554-563.

65. Narasimhan M, Ammanamanchi S: Curcumin blocks RON tyrosine kinase-mediated invasion of breast carcinoma cells. Cancer Res 2008, 68(13):5185-5192.

66. Rochette-Egly C, Chambon P: F9 embryocarcinoma cells: a cell autonomous model to study the functional selectivity of RARs and RXRs in retinoid signaling. Histol Histopathol 2001, 16(3):909-922

67. Kang S, Duell EA, Fisher GJ, Datta SC, Wang ZQ, Reddy AP, Tavakkol A, Yi JY, Griffiths CE, Elder JT, Voorhees JJ: Application of retinol to human skin in vivo induces epidermal hyperplasia and cellular retinoid binding proteins characteristic of retinoic acid but without measurable retinoic acid levels or irritation. J Invest Dermatol 1995, 105(4):549-556.

68. Zouboulis CC: Retinoids-which dermatological indications will benefit in the near future? Skin Pharmacol App/ Skin Physiol 2001, 14(5):303-315.

69. Verma AK, Conrad EA, Boutwell RK: Differential effects of retinoic acid and 7,8-benzoflavone on the induction of mouse skin tumors by the complete carcinogenesis process and by the initiation-promotion regimen. Cancer Res 1982, 42(9):3519-3525.

70. Degenhardt T, Saramaki A, Malinen M, Rieck M, Vaisanen S, Huotari A, Herzig KH, Muller R, Carlberg C: Three members of the human pyruvate dehydrogenase kinase gene family are direct targets of the peroxisome proliferator-activated receptor beta/delta. J Mol Biol 2007, 372(2):341-355.

71. Burdick AD, Bility MT, Girroir EE, Billin AN, Willson TM, Gonzalez FJ, Peters JM: Ligand activation of peroxisome proliferator-activated receptor-beta/delta (PPARbeta/delta) inhibits cell growth of human N/TERT-1 keratinocytes. Cell Signal 2007, 19(6):1163-1171.

72. Hwang I, Kim J, Jeong S: beta-Catenin and peroxisome proliferator-activated receptor-delta coordinate dynamic chromatin loops for the transcription of vascular endothelial growth factor A gene in colon cancer cells. J Bio/ Chem 2012, 287(49):41364-41373.

73. Lee H, Park HJ, Park CS, Oh ET, Choi BH, Williams B, Lee CK, Song CW: Response of breast cancer cells and cancer stem cells to metformin and hyperthermia alone or combined. PLoS One 2014, 9(2):e87979.

74. Ali S, Ahmad A, Banerjee S, Padhye S, Dominiak K, Schaffert JM, Wang Z, Philip PA, Sarkar FH: Gemcitabine sensitivity can be induced in pancreatic cancer cells through modulation of miR-200 and miR-21 expression by curcumin or its analogue CDF. Cancer Res 2010, 70(9):3606-3617.

75. Chiu TL, Su CC: Curcumin inhibits proliferation and migration by increasing the Bax to $\mathrm{Bcl}-2$ ratio and decreasing NF-kappaBp65 expression in breast cancer MDA-MB-231 cells. Int J Mol Med 2009, 23(4):469-475.

76. Lv ZD, Liu XP, Zhao WJ, Dong Q, Li FN, Wang HB, Kong B: Curcumin induces apoptosis in breast cancer cells and inhibits tumor growth in vitro and in vivo. Int J Clin Exp Pathol 2014, 7(6):2818-2824.

77. Yue GG, Chan BC, Hon PM, Lee MY, Fung KP, Leung PC, Lau CB: Evaluation of in vitro anti-proliferative and immunomodulatory activities of compounds isolated from Curcuma longa. Food Chem Toxicol 2010, 48(8-9):2011-2020.

78. Parasramka MA, Gupta SV: Synergistic effect of garcinol and curcumin on antiproliferative and apoptotic activity in pancreatic cancer cells. J Oncol 2012, 2012:709739.

79. Chang CC, Fu CF, Yang WT, Chen TY, Hsu YC: The cellular uptake and cytotoxic effect of curcuminoids on breast cancer cells. Taiwan J Obstet Gynecol 2012, 51(3):368-374.

80. Kunwar A, Barik A, Mishra B, Rathinasamy K, Pandey R, Priyadarsini Kl: Quantitative cellular uptake, localization and cytotoxicity of curcumin in normal and tumor cells. Biochim Biophys Acta 2008, 1780(4):673-679.

81. Cen L, Hutzen B, Ball S, DeAngelis S, Chen CL, Fuchs JR, Li C, Li PK, Lin J: New structural analogues of curcumin exhibit potent growth suppressive activity in human colorectal carcinoma cells. BMC Cancer 2009, 9:99.

82. Shieh JM, Chen YC, Lin YC, Lin JN, Chen WC, Chen YY, Ho CT, Way TD: Demethoxycurcumin inhibits energy metabolic and oncogenic signaling pathways through AMPK activation in triple-negative breast cancer cells. J Agric Food Chem 2013, 61(26):6366-6375.

83. Dayton A, Selvendiran K, Kuppusamy ML, Rivera BK, Meduru S, Kalai T, Hideg K, Kuppusamy P: Cellular uptake, retention and bioabsorption of $\mathrm{HO}-$ 3867, a fluorinated curcumin analog with potential antitumor properties. Cancer Biol Ther 2010, 10(10):1027-1032.

84. Chainani-Wu N: Safety and anti-inflammatory activity of curcumin: a component of tumeric (Curcuma longa). J Altern Complement Med 2003, 9(1):161-168.

85. Kanwar SS, Yu Y, Nautiyal J, Patel BB, Padhye S, Sarkar FH, Majumdar AP: Difluorinated-curcumin (CDF): a novel curcumin analog is a potent inhibitor of colon cancer stem-like cells. Pharm Res 2011, 28(4):827-838.

86. Meiyanto E, Putri DD, Susidarti RA, Murwanti R, Sardjiman, Fitriasari A, Husnaa U, Purnomo H, Kawaichi M: Curcumin and its analogues (PGV-0 and PGV-1) enhance sensitivity of resistant MCF-7 cells to doxorubicin through inhibition of HER2 and NF-kB activation. Asian Pac J Cancer Prev 2014, 15(1):179-184.

87. Jing C, Beesley C, Foster CS, Rudland PS, Fujii H, Ono T, Chen H, Smith PH, Ke $Y$ : Identification of the messenger RNA for human cutaneous fatty acidbinding protein as a metastasis inducer. Cancer Res 2000, 60(9):2390-2398.

88. Adamson J, Morgan EA, Beesley C, Mei Y, Foster CS, Fujii H, Rudland PS, Smith $\mathrm{PH}, \mathrm{Ke}$ Y: High-level expression of cutaneous fatty acid-binding protein in prostatic carcinomas and its effect on tumorigenicity. Oncogene 2003, 22(18):2739-2749.

89. Morgan EA, Forootan SS, Adamson J, Foster CS, Fujii H, Igarashi M, Beesley C, Smith PH, Ke Y: Expression of cutaneous fatty acid-binding protein (C-FABP) in prostate cancer: potential prognostic marker and target for tumourigenicity-suppression. Int J Oncol 2008, 32(4):767-775.

90. Ranjan AP, Mukerjee A, Helson L, Gupta R, Vishwanatha JK: Efficacy of liposomal curcumin in a human pancreatic tumor xenograft model: inhibition of tumor growth and angiogenesis. Anticancer Res 2013, 33(9):3603-3609.

91. Orr WS, Denbo JW, Saab KR, Myers AL, Ng CY, Zhou J, Morton CL, Pfeffer LM, Davidoff AM: Liposome-encapsulated curcumin suppresses neuroblastoma growth through nuclear factor-kappa B inhibition. Surgery 2012, 151(5):736-744.

92. Wang D, Veena MS, Stevenson K, Tang C, Ho B, Suh JD, Duarte VM, Faull KF, Mehta K, Srivatsan ES, Wang MB: Liposome-encapsulated curcumin suppresses growth of head and neck squamous cell carcinoma in vitro and in xenografts through the inhibition of nuclear factor kappaB by an AKT-independent pathway. Clin Cancer Res 2008, 14(19):6228-6236.

doi:10.1186/1471-2407-14-724

Cite this article as: Thulasiraman et al.: Curcumin restores sensitivity to retinoic acid in triple negative breast cancer cells. BMC Cancer 2014 14:724.

\section{Submit your next manuscript to BioMed Central and take full advantage of:}

- Convenient online submission

- Thorough peer review

- No space constraints or color figure charges

- Immediate publication on acceptance

- Inclusion in PubMed, CAS, Scopus and Google Scholar

- Research which is freely available for redistribution 